\title{
The diversity and physiological activities of weeds in land cultivated with various corn cultivars and fertilized with various nitrogen doses
}

\author{
MUJI RAHAYU ${ }^{1,3, \boldsymbol{v}}$, PRAPTO YUDONO ${ }^{2}$, DIDIK INDRADEWA ${ }^{2}$, EKO HANUDIN $^{2}$ \\ ${ }^{1}$ Faculty of Agriculture, Universitas Sebelas Maret. Jl. Ir. Sutami 36A Surakarta 57 126, Central Java, Indonesia. Tel./fax. +62-271-637457 Ext. 129, \\ "email: mujirahayu@ staff.uns.ac.id \\ ${ }^{2}$ Faculty of Agriculture, Universitas Gadjah Mada. Sleman 55281, Yogyakarta, Indonesia \\ ${ }^{3}$ Program of Agricultural Sciences, Faculty of Agriculture, Universitas Gadjah Mada. Sleman 55281, Yogyakarta, Indonesia
}

Manuscript received: 20 November 2018. Revision accepted: 6 February 2019.

\begin{abstract}
Rahayu M, Yudono P, Indradewa D, Hanudin E. 2019. The diversity and physiological activities of weeds in land cultivated with various corn cultivars and fertilized with various nitrogen doses. Biodiversitas 20: 622-628. Both weeds and corn have nutrient needs. Nitrogen is one of the essential elements required by weeds and corn. Each corn cultivar and weed also has different ability to absorb nitrogen. This study aimed to determine the effect of corn cultivar and nitrogen dose on the diversity and physiological activities of weeds. The research was conducted in Banguntapan, Bantul, Yogyakarta from December 2016 to May 2017. The study used a completely randomized block design with 2 factors with three replications. The first factor was corn cultivar, consisting of four cultivars (Bisi 18, NK 33, DK 95 and Sukmaraga) and the second factor was the nitrogen dose, consisting of three levels $\left(25 \mathrm{~kg} \mathrm{~N} \mathrm{ha}^{-1}, 150 \mathrm{~kg} \mathrm{~N}\right.$ $\mathrm{ha}^{-1}$ and $275 \mathrm{~kg} \mathrm{~N} \mathrm{ha}^{-1}$ ). The data were analyzed using 5\% variance analysis and continued with Duncan test at 5\% level. The results showed that the most commonly found weeds were broadleaves, but the most dominant weed was a grass, namely Dactyloctenium aegyptium, except Sukmaraga with nitrogen doses of $25 \mathrm{~kg} \mathrm{ha}^{-1}$ and $150 \mathrm{~kg} \mathrm{ha}^{-1}$ in 4 weeks after planting (WAP). In 8 WAP, weeds that grew in land planted with all combinations of cultivars and nitrogen doses were Cyperus rotundus, Dactyloctenium aegyptium, Digitaria ciliaris, Eleusine indica, Eragrostis tenella, Amaranthus spinosus, and Richardia scabra. There were no significant differences on the nitrate reductase activity, chlorophyll content, leaf area index, and dry weight among cultivars. The treatment of $25 \mathrm{~kg} \mathrm{~N}^{-1} \mathrm{resulted} \mathrm{in}$ the lowest leaf area index and total chlorophyll content, but the highest nitrate reductase activity.
\end{abstract}

Keywords: Corn cultivar, nitrogen dose, physiological activity, weed diversity

\section{INTRODUCTION}

The diversity in ecology is generally meant as the species diversity determined by integrating the number of species in the community and the relative abundance of each species (McNaughton \& Wolf, 1990). Weed can be interpreted as a plant which, if allowed to grow in a plant cultivation system, will cause a financial loss, both directly and indirectly (Tohari 2017).

Weed composition and diversity are influenced by many factors, including climate, edaphic, and biotic factors (Rao 2000). Previous researches showed that weed composition and diversity vary among regions. The results of weed vegetation analysis in corn plantation in Lambung Bukit Village, Padang, West Sumatra, obtained 10 families, 15 genera, 16 species, and 1892 individuals of weeds (Oksari 2014). During 2010-2013 in South Western Cameroon, there were 53 species of weeds which caused corn yield loss. The five most dominant weeds in corn field were Amaranthus spinosus, Bidens pilosa, Commelina benghalensis, Mariscus alternafolius and Cynodon dactylon (Ndam et al. 2014).

The diversity of weeds is also found in different environments. From 2013 to 2017, in the southern region of Ilmen State Reserve Russia, 51 species of weeds were found, consisting of 4 genera and 6 weed families (Mashkova et al. (2018). Sunaryo and Girmansyah (2015) also reported that the vegetation in 4 regions in Tanjung Putting National Park consisted of 31 species of invasive plants from 12 families. In the community forest of albizia in Boyolali there were 13 families of weeds consisting of 67 species (Marsusi 2012).

The weed diversity is also affected by agricultural system applied. Kolarova et al. (2015) reported that the highest number of weed species was found in winter cereal plantation and in medium altitude. Chenopodium album was the highest weed species in conventional and organic farming system. Edesi et al. (2012) also reported that an average number of weed species was higher in organic system than conventional treatment.

Weed has the same resource requirement as cultivated plants, so when they grow together there will be a competition. The competitiveness of each plant variety is different, so changes in the plant varieties planted will affect the composition of weed population (Tohari 2017). On rice, the competitive cultivar (Sarinah) more effectively suppressed the dry weight of sedges and grasses than IR64, but had no influence on dry weight of broadleaved weeds. Despite reducing total weed dry weight, use of a competitive cultivar had no effect on the density and species number of weed (Haden et al. 2007).

Nitrogen is one of the macronutrients needed by both the cultivated plants and weeds. Pachta et al. (2013) reported that corn and Palmer Amaranth gave the same 
response to the application of nitrogen. The nitrogen content in corn and weed tissue increased with the increased amount of nitrogen applied from 0 to $224 \mathrm{~kg} \mathrm{~N}$ $\mathrm{ha}^{-1}$. Rao (2000) states that weeds can absorb nutrients in large quantities compared to the cultivated plants. The availability of nitrogen will also affect the physiological activities of weed, including chlorophyll production, and nitrate reductase activity. Thus, the physiological activities that occur in the weeds will affect the competitiveness of weeds to the cultivated plants.

The presence of weeds and limited availability of nutrients can cause changes in weed composition and physiological activities of weeds and cultivated plants, which can cause a decrease in corn yield. This study aimed to measure the diversity and physiological activities of weeds that grew with various corn cultivars fertilized with various nitrogen doses.

\section{MATERIALS AND METHODS}

\section{Time and place}

The study was carried out in the experimental field of Gadjah Mada University in Banguntapan, Yogyakarta, Indonesia from December 2016 to May 2017. Analysis of physiological activities was conducted in the Management and Crop Production Laboratory and Plant Science Laboratory Gadjah Mada University, Yogyakarta.

\section{Land preparation}

Prior to planting corn, tillage was done with a hand tractor and then flattened with a hoe. Further, the land was divided into 3 blocks and created plots with size about 350 $\mathrm{cm} \times 200 \mathrm{~cm}$. The plot was high about $30 \mathrm{~cm}$. The distance between plots was $50 \mathrm{~cm}$ and the distance between blocks was $100 \mathrm{~cm}$. Corn planting distance was $70 \mathrm{~cm}$ x $20 \mathrm{~cm}$, so that the population of corn was 50 plants per plot.

\section{Fertilization}

Fertilizer was given to corn consisting of SP-36 $100 \mathrm{~kg}$ $\mathrm{ha}^{-1}, 100 \mathrm{~kg} \mathrm{KCl} \mathrm{ha}{ }^{-1}$ and urea (nitrogen). The doses of nitrogen accordance to each treatment. SP-36 and $\mathrm{KCl}$ were given in 7 days after planting, while urea was given three times. One third was given in 7 days after planting, $1 / 3$ doses were given 24 days after planting and 1/3 of dose was given in 40 days after planting. The fertilizer applied per plant with a distance of $7 \mathrm{~cm}$ from the planting hole.

\section{Experimental design and physiological activity evaluation}

The experimental design used in this study was a completely randomized block design with 2 treatment factors and three replications. The first factor was corn cultivar, consisting of four cultivars (Bisi 18, NK 33, DK 95 and Sukmaraga) and the second factor was the nitrogen dose, consisting of three levels $\left(25 \mathrm{~kg} \mathrm{~N} \mathrm{ha}^{-1}, 150 \mathrm{~kg} \mathrm{~N} \mathrm{ha}^{-1}\right.$ and $275 \mathrm{~kg} \mathrm{~N} \mathrm{ha}^{-1}$ ).

Weeds were sampled using quadrats, each measuring $70 \mathrm{~cm} \times 20 \mathrm{~cm}$. The weeds were identified, cut, dried in oven about 48 hours and weighed. Leaf area was measured using a leaf area meter and it was used for calculating the leaf area index. Chlorophyll content was measured in 8 weeks after planting (WAP). In a digital scale, $0.05 \mathrm{~g}$ of fresh leaves were measured separately. Samples were maturated in $80 \%$ acetone. These were then centrifuged for 10 minutes and finally made a volume of $5 \mathrm{ml}$ with acetone (80\%). The optical density was measured at $645 \mathrm{~nm}$ and $663 \mathrm{~nm} \lambda$ with a spectrophotometer. (Islam et al. 2009). Measurement of nitrate reductase activity was conducted this way: the leaves were washed with distilled water, then cut into small pieces, approximately $1 \mathrm{~mm}$ each. Leaf pieces as much as $200 \mathrm{mg}$ were inserted in the dark film tube containing $0.1 \mathrm{M}$ sodium phosphate buffer solution as much as $5 \mathrm{ml}$ and incubated for 24 hours. Then the buffer solution was replaced with the new buffer solution and added with $0.1 \mathrm{ml} 0.1 \mathrm{M} \mathrm{NaNO} 3$ as the substrate and the start of incubation was recorded. After having been incubated for 2 hours, $0.1 \mathrm{ml}$ of the filtrate was taken and put into test tubes containing dye reagent, consisting of 0.2 $\mathrm{ml} 0.02 \%$ solution of $\mathrm{N}-\mathrm{Naphthylethylene} \mathrm{diamine} \mathrm{and} 0.2$ $\mathrm{ml}$ of $1 \% \mathrm{HCl}$ in sulfanilamide $3 \mathrm{~N}$. Then, after at least 15 minutes until its color turned pink, then $2.5 \mathrm{ml}$ distilled water was added. One test tube was not given the filtrate and was used as a blank. Then its absorbance was measured with a spectrophotometer Shimadzu 121 at 540 $\mathrm{nm} \lambda$. The activity of nitrate reductase, nitrate/micromol are expressed in grams of leaves every hour using the following formula:

$$
\text { NRA }=\frac{\text { abs sampel }}{\text { abs standart }} \times \frac{1000}{B B} \times \frac{1}{W 1} \times \frac{50}{1000}
$$

Where:

NRA: Nitrate reductase activity; Absorbance standard: 0.0142 ; BB: Wet weight (mg)

W1 : Incubation time (hour) (Danususila 1989)

\section{Data analyses}

The weed data were analyzed to get the absolute density, absolute frequency, and absolute dominance, and the summed dominance ratio (SDR) of each species. The other data obtained consisting of nitrate reductase activity, chlorophyll content, leaf area index, and dry weight was analyzed using analysis of variance (ANOVA) at the level of $5 \%$ and continued with Duncan test at $5 \%$ level.

\section{RESULTS AND DISCUSSION}

\section{Number of weed species}

Based on their morphology, weeds are classified into Cyperaceae, grass, and broadleaf (Tohari 2017). The composition and diversity of weeds are influenced by several factors, including the age of cultivated plants. The number of weed species that grew in 8 WAP was different from that in 4 WAP (Table 1).

Table 1 shows that the most species of weed growing in $4 \mathrm{WAP}$ and $8 \mathrm{WAP}$ in all treatment combinations were broadleaves. The same results were reported by Oksari (2014) that the widest distributed weed in corn plantations in Lambung Bukit Village, Padang, West Sumatra was a 
broadleaf (1748 individuals). The composition of weeds that grew in each treatment was different. In 4 WAP, there were 2 types of weed growing in all treatments, except for 2 cultivars which had 3 types of weed (Bisi 18 cultivar with a dose of $275 \mathrm{~kg} \mathrm{~N}^{-1}$ and DK 95 with a dose of $25 \mathrm{~kg} \mathrm{~N}$ $\mathrm{ha}^{-1}$ and $275 \mathrm{~kg} \mathrm{~N} \mathrm{ha}^{-1}$ ). Both grasses and broadleaves grew in the different numbers which were 1 to 3 species and 9 to 13 species respectively. The application of nitrogen at a dose of $275 \mathrm{~kg} \mathrm{~N} \mathrm{ha}{ }^{-1}$ increased the number of weed species that grew in all corn plantations with different cultivars. In $8 \mathrm{WAP}$, there was a decrease in the number of weed species which grew in all plantations with different cultivars.

\section{The species composition and diversity of weed communities in 4 WAP}

The number of weed species growing in the corn plantation at 4 WAP was 30 species which consisted of 3 species of Cyperaceae, 7 species of grasses and 20 species of broadleaves. Broadleaves were the most widely growing weeds in corn plantation with all combinations of corn cultivars with nitrogen doses, namely Boerhavia erecta, Hedyotis corymbosa, Phyllanthus niruri, Physalis angulata, and Richardia scabra.

The Cyperaceae growing in plantation with all treatment combinations were Bulbostylis puberula and Cyperus rotundus. The weed species having the highest SDR was Puberula Bulbostylis which grew in plantation with treatment combination of DK 95 and a dose of $275 \mathrm{~kg}$ $\mathrm{N} \mathrm{ha}{ }^{-1}$, while the lowest SDR grew in plantation with treatment combination of Bisi 18 and a dose of $25 \mathrm{~kg} \mathrm{~N}$ ha 1. C. rotundus was the most widely distributed in Sukmaraga with dose of $150 \mathrm{~kg} \mathrm{~N} \mathrm{ha}{ }^{-1}$, while the lowest SDR resulted from the treatment combination of Bisi 18 and dose of $275 \mathrm{~kg} \mathrm{~N} \mathrm{ha}{ }^{-1}$. The grasses that grew in land with all treatment combinations were Dacytiloctenium aegyptium, Eleusine indica and Panicum distachyum, D. aegyptium was the species of weed that grew in plantation with all treatment combinations with the highest SDR value except for Sukmaraga with nitrogen dose of $25 \mathrm{~kg} \mathrm{~N}^{-1}$ and $150 \mathrm{~kg} \mathrm{~N}$ ha, ${ }^{-1}$ which resulted in the highest SDR value on $C$. rotundus (Table 2 ).

\section{The species composition and diversity of weed communities in 8 WAP}

The composition of weed species that grew when the corn plant in 8 WAP was different from that in 4 WAP, which consisted of 26 species, 3 of which were Cyperaceae, 6 grasses and 17 broadleaves. The composition of weed that grew in plantation with all combinations of treatment varied.

The species of Cyperaceae that grew in the plantation with all combinations of various cultivars and nitrogen doses was Cyperus rotundus with the highest SDR value resulted from the treatment combination of NK 33 with a dose of $275 \mathrm{~kg} \mathrm{~N} \mathrm{ha}{ }^{-1}$, while the grasses were $D$. aegyptium, D. ciliaris, E. indica, and E. tenella. The broadleaf weeds were the most common types of weeds in all treatment combinations. The number broadleaf weeds that grew ranged from 6 to 12 species with varying diversities among the treatment combinations. Overall, $D$. aegyptium was the weed that grew in plantation with all treatment combinations with the highest SDR value. Three weed species that had the highest SDR value and dominant in all treatments were C. rotundus. D. aegyptium and $E$. indica (Table 2 and 3). Kastanja (2015) reported that the most dominant weed that grows in sweet corn field with different age is almost uniform which are from the family of Capparidiceae, Cyperaceae, Poaceae, and Portulacaceae.

Leaf area index affects photosynthetic rate in weed as well as cultivated plants. There was no interaction between corn cultivars and nitrogen doses on the leaf area index in 8 WAP. Cultivar did not significantly affect leaf area index, but nitrogen did. The influence of nitrogen dose on leaf area index is presented in Figure 1.

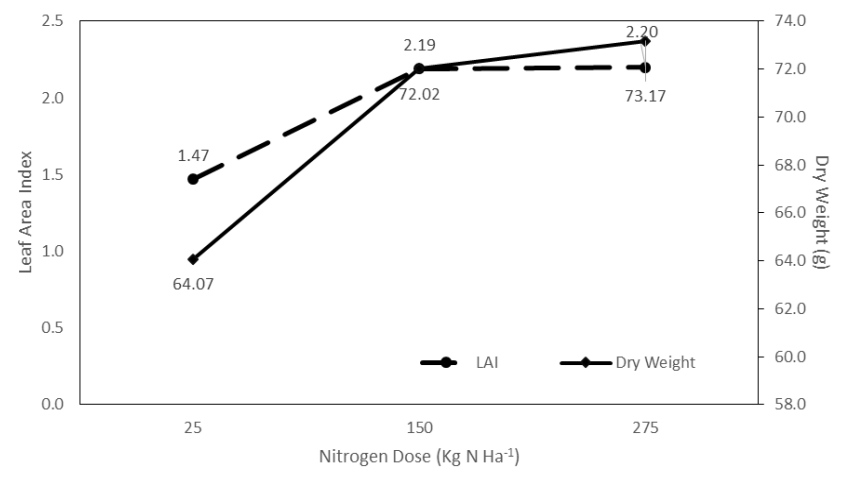

Figure 1. The effect of nitrogen levels on leaf area index and dry weight of biomass

Table 1. The number of weed species in land planted with various corn cultivars and nitrogen doses in 4 and 8 WAP

\begin{tabular}{|c|c|c|c|c|c|c|c|c|c|c|c|c|c|c|c|c|c|c|c|c|}
\hline \multirow{4}{*}{ Cultivars } & \multicolumn{20}{|c|}{ Nitrogen doses } \\
\hline & \multicolumn{6}{|c|}{4 WAP } & \multicolumn{14}{|c|}{8 WAP } \\
\hline & \multicolumn{2}{|c|}{25 kg N ha $^{-1}$} & \multicolumn{2}{|c|}{$150 \mathrm{~kg} \mathrm{~N} \mathrm{ha}^{-1}$} & \multicolumn{2}{|c|}{$275 \mathrm{~kg} \mathrm{~N} \mathrm{ha}^{-1}$} & \multirow{2}{*}{ Average } & \multicolumn{4}{|c|}{$25 \mathrm{~kg} \mathrm{~N} \mathrm{ha}^{-1}$} & \multicolumn{4}{|c|}{$150 \mathrm{~kg} \mathrm{~N} \mathrm{ha}^{-1}$} & \multicolumn{4}{|c|}{$275 \mathrm{~kg} \mathrm{~N} \mathrm{ha}^{-1}$} & \multirow[t]{2}{*}{ Average } \\
\hline & C G B & Sum & C G B & Sum & C G B & Sum & & C & G & B & Sum & C & G & B & Sum & C & $\mathbf{G}$ & B & Sum & \\
\hline Bisi 18 & $\begin{array}{lll}2 & 6 & 11\end{array}$ & 19 & $\begin{array}{lll}2 & 6 & 9\end{array}$ & 17 & $\begin{array}{llll}3 & 5 & 13\end{array}$ & 21 & 19.00 & 3 & 4 & 10 & 17 & 3 & 4 & 11 & 18 & 2 & 5 & 9 & 16 & 17.00 \\
\hline NK 33 & 266 & 17 & $\begin{array}{lll}2 & 6 & 10\end{array}$ & 18 & 2710 & 19 & 18.00 & 3 & 5 & 12 & 20 & 1 & 4 & 7 & 12 & 3 & 5 & 6 & 14 & 15.33 \\
\hline DK 95 & $\begin{array}{lll}3 & 5 & 10\end{array}$ & 18 & $\begin{array}{lll}2 & 5 & 10\end{array}$ & 17 & 3711 & 21 & 18.67 & 2 & 5 & 9 & 16 & 2 & 6 & 8 & 16 & 2 & 4 & 8 & 14 & 15.33 \\
\hline Sukmaraga & 269 & 17 & 2410 & 16 & 2512 & 19 & 17.33 & 3 & 5 & 10 & 18 & 2 & 5 & 12 & 19 & 1 & 5 & 6 & 12 & 16.33 \\
\hline Average & & 17.75 & & 17.00 & & 20.00 & & & & & 17.75 & & & & 16.25 & & & & 14.00 & \\
\hline
\end{tabular}

Note: C: Cyperaceae; G: Grasses; B: Broadleaf. 
Table 2. Summed Dominance Ratio (\%) of weed species in 4 WAP

\begin{tabular}{|c|c|c|c|c|c|c|c|c|c|c|c|c|}
\hline \multirow{4}{*}{ Weed species } & \multicolumn{12}{|c|}{ Cultivars } \\
\hline & \multicolumn{3}{|c|}{ Bisi 18} & & \multicolumn{3}{|c|}{ DK 95} & \multicolumn{3}{|c|}{ Sukmaraga } \\
\hline & \multicolumn{11}{|c|}{ Nitrogen Dose $\left(\mathrm{kg} \mathrm{N} \mathrm{ha}^{-1}\right)$} & \\
\hline & 25 & 150 & 275 & 25 & 150 & 275 & 25 & 150 & 275 & 25 & 150 & 275 \\
\hline \multicolumn{13}{|l|}{ Cyperaceae } \\
\hline Bulbostylis puberula & 3.6 & 5.6 & 4.2 & 4.9 & 5.3 & 4.9 & 3.4 & 5.3 & 7.1 & 4.7 & 3.9 & 5.4 \\
\hline Cyperus iria & 0.0 & 0.0 & 2.8 & 0.0 & 0.0 & 0.0 & 1.5 & 0.0 & 2.1 & 0.0 & 0.0 & 0.0 \\
\hline Cyperus rotundus & 17.3 & 14.6 & 12.0 & 15.7 & 16.9 & 17.9 & 14.9 & 18.6 & 19.7 & 20.7 & 21.4 & 10.7 \\
\hline \multicolumn{13}{|l|}{ Grasses } \\
\hline Dacyoloctenium aegyptium & 30.8 & 20.9 & 20.5 & 25.9 & 22.4 & 26.5 & 18.1 & 24.1 & 22.2 & 16.3 & 18.9 & 22.0 \\
\hline Digitaria ciliaris & 1.3 & 5.4 & 2.1 & 5.4 & 5.2 & 2.3 & 7.2 & 4.5 & 2.4 & 9.0 & 0.0 & 8.4 \\
\hline Eleusine indica & 11.0 & 12.6 & 16.8 & 11.5 & 13.7 & 9.5 & 24.9 & 8.0 & 13.4 & 18.4 & 11.1 & 15.8 \\
\hline Eragrostis tenela & 1.3 & 3.1 & 0.0 & 4.9 & 1.2 & 4.4 & 1.6 & 1.2 & 3.4 & 2.8 & 3.1 & 3.5 \\
\hline Ischaemum thimorense & 0.0 & 0.0 & 0.0 & 0.0 & 0.0 & 3.2 & 0.0 & 0.0 & 1.3 & 0.0 & 0.0 & 0.0 \\
\hline Panicum distachyum & 2.3 & 3.8 & 3.7 & 5.2 & 5.5 & 1.4 & 3.5 & 7.0 & 1.1 & 3.1 & 9.7 & 6.0 \\
\hline Paspalum conjugatum & 3.4 & 1.8 & 2.6 & 2.2 & 3.6 & 1.3 & 0.0 & 0.0 & 1.2 & 2.3 & 0.0 & 0.0 \\
\hline \multicolumn{13}{|l|}{ Broadleaf } \\
\hline Aeschinomene americana & 1.1 & 0.0 & 0.0 & 0.0 & 0.0 & 0.0 & 0.0 & 0.0 & 0.0 & 0.0 & 0.0 & 0.0 \\
\hline Amaranthus spinosus & 3.6 & 9.2 & 3.8 & 2.0 & 4.2 & 0.0 & 0.0 & 5.4 & 1.8 & 4.1 & 5.0 & 5.2 \\
\hline Boerhaavia erecta & 6.2 & 2.8 & 3.0 & 3.0 & 1.3 & 5.9 & 1.2 & 4.4 & 3.8 & 0.0 & 3.0 & 2.6 \\
\hline Cleome rutidosperma & 2.6 & 3.1 & 4.0 & 2.8 & 3.2 & 5.1 & 3.6 & 0.0 & 2.8 & 1.5 & 4.4 & 3.0 \\
\hline Commelina diffusa & 0.0 & 0.0 & 0.0 & 0.0 & 0.0 & 0.0 & 0.0 & 0.0 & 0.0 & 0.0 & 0.0 & 0.0 \\
\hline Croton hirtus & 0.0 & 0.0 & 1.0 & 2.0 & 0.0 & 1,3 & 0.0 & 3.5 & 1.5 & 1.6 & 0.0 & 1.3 \\
\hline Euphorbia heterophyla & 0.0 & 0.0 & 1.0 & 0.0 & 0.0 & 0.0 & 1.9 & 0.0 & 0.0 & 3.3 & 0.0 & 1.9 \\
\hline Euphorbia hirta & 0.0 & 0.0 & 0.0 & 0.0 & 1.1 & 0.0 & 1.2 & 0.0 & 1.0 & 0.0 & 0.0 & 1.4 \\
\hline Gynandropsis gynandra & 0.0 & 0.0 & 0.0 & 0.0 & 0.0 & 0.0 & 0.0 & 0.0 & 2.5 & 0.0 & 1.6 & 0.0 \\
\hline Hedyotis corymbosa & 1.1 & 1.9 & 2.8 & 2.6 & 3.7 & 5.1 & 2.3 & 3.6 & 3.0 & 4.1 & 2.9 & 1.2 \\
\hline Lindernia ciliata & 1.7 & 0.0 & 3.5 & 2.6 & 2.6 & 2.8 & 3.5 & 1.0 & 0.0 & 1.3 & 0.0 & 0.0 \\
\hline Lindernia crustacea & 0.0 & 2.0 & 0.0 & 0.0 & 0.0 & 0.0 & 0.0 & 1.1 & 0.0 & 0.0 & 0.0 & 0.0 \\
\hline Murdania blumei & 0.0 & 0.0 & 0.0 & 0.0 & 0.0 & 0.0 & 0.0 & 0.0 & 0.0 & 0.0 & 1.1 & 0.0 \\
\hline Melochia piramidata & 0.0 & 0.0 & 1.1 & 0.0 & 1.1 & 0.0 & 0.0 & 0.0 & 0.0 & 0.0 & 0.0 & 1.2 \\
\hline Ocimum sanctum & 1.3 & 0.0 & 1.2 & 0.0 & 0.0 & 1.4 & 1.2 & 2.2 & 0.0 & 0.0 & 0.0 & 0.0 \\
\hline Philanthus niruri & 3.6 & 1.5 & 2.4 & 2.9 & 3.1 & 1.5 & 2.3 & 1.5 & 2.3 & 1.1 & 2.5 & 2.7 \\
\hline Physalis angulata & 3.6 & 4.0 & 3.1 & 3.6 & 1.8 & 3.5 & 2.9 & 3.5 & 2.0 & 4.5 & 4.3 & 1.5 \\
\hline Portulaca oleraceae & 0.0 & 1.7 & 2.1 & 0.0 & 0.0 & 0.0 & 0.0 & 0.0 & 0.0 & 0.0 & 1.3 & 0.0 \\
\hline Richardia scabra & 3.2 & 6.1 & 6.4 & 3.0 & 4.2 & 2.0 & 5.0 & 5.2 & 3.1 & 1.4 & 5.9 & 5.0 \\
\hline Sida spinosa & 1.2 & 0.0 & 0.0 & 0.0 & 0.0 & 0.0 & 0.0 & 0.0 & 2.1 & 0.0 & 0.0 & 1.3 \\
\hline
\end{tabular}

\section{Leaf area index of the weeds}

The application of $25 \mathrm{~kg} \mathrm{~N} \mathrm{ha}^{-1}$ resulted in the lowest leaf area index of the weeds. Increasing the doses of nitrogen into $150 \mathrm{~kg} \mathrm{~N} \mathrm{ha}^{-1}$ and $275 \mathrm{~kg} \mathrm{~N} \mathrm{ha}^{-1}$ increased the leaf area index The highest leaf area index was found at the application of $275 \mathrm{~kg} \mathrm{~N} \mathrm{ha}^{-1}$. The weed leaf area index is influenced by the weed leaf area. This shows that low nitrogen application $\left(25 \mathrm{~kg} \mathrm{~N} \mathrm{ha}^{-1}\right)$ was insufficient for the need for the weed growth, which affected the weed leaf area (Figure 1).

\section{The weed dry weight}

Each species of the weed has a different ability to grow in a certain area, which will affect its production capacity of biomass. Salehian and Eshagi (2012) reported that among the five species of the weed (wild oat, wild mustard, little seed canarygrass, hood canary grass and ryegrass), wild oat had the highest leaf area and dry weight, whereas wild mustard had the smallest leaf area and dry weight. In this study, the measurement of weed dry weight was conducted for the whole dry weight of all species of the weed that grew in each treatment, without separating each species.

In $8 \mathrm{WAP}$, the weed dry weight produced in plantation with each corn cultivar was the same. The results of Didon (2002) study also showed that there was no significant difference in dry weight of the weed in plantation with three barley cultivars (Svani, Lina, Jessica).

Figure 1 shows that the weed dry weight increased as nitrogen dose increased. Adigun et al. (2018) reported that an increase application of $\mathrm{N}$ to $90 \mathrm{~kg} \mathrm{~N} \mathrm{ha}^{-1}$ increased weed density and dry weight. The increased $\mathrm{N}$ dose also improved the growth and yield of okra.

\section{Nitrate reductase activity (NRA)}

Nitrate reductase is one of the important enzymes in nitrate metabolism. It reduces nitrate into nitrite. The results of the variance analysis showed that there was an interaction between cultivars and various doses of nitrogen on weed nitrate reductase activity. There was no difference in weed NRA in all cultivars (Table 4), while nitrogen dose significantly affected the NRA (Figure 2). 
Table 3. Summed Dominance Ratio (\%) in 8 WAP

\begin{tabular}{|c|c|c|c|c|c|c|c|c|c|c|c|c|}
\hline \multirow{4}{*}{ Weed species } & \multicolumn{12}{|c|}{ Cultivars } \\
\hline & \multicolumn{3}{|c|}{ Bisi 18} & \multicolumn{3}{|c|}{ NK 33} & \multicolumn{3}{|c|}{ DK 95} & \multicolumn{3}{|c|}{ Sukmaraga } \\
\hline & \multicolumn{12}{|c|}{ Nitrogen Doses $\left(\mathrm{kg} \mathrm{N} \mathrm{ha}^{-1}\right)$} \\
\hline & 25 & 150 & 275 & 25 & 150 & 275 & 25 & 150 & 275 & 25 & 150 & 275 \\
\hline \multicolumn{13}{|l|}{ Cyperaceae } \\
\hline Bulbostylis puberula & 4.2 & 1.4 & 0.0 & 1.17 & 0.0 & 1.4 & 0.0 & 0.0 & 0.0 & 3.1 & 0.0 & 0.0 \\
\hline Cyperus iria & 4.1 & 2.0 & 3.2 & 2.35 & 0.0 & 2.8 & 2.7 & 1.9 & 2.9 & 8.5 & 3.0 & 0.0 \\
\hline Cyperus rotundus & 5.9 & 9.5 & 14.4 & 13.05 & 13.2 & 13.3 & 7.6 & 11.5 & 9.3 & 3.9 & 9.7 & 13.9 \\
\hline \multicolumn{13}{|l|}{ Grasses } \\
\hline Dactyoloctenium aegyptium & 41.5 & 44.2 & 27.9 & 28.30 & 33.7 & 31.5 & 35.2 & 40.4 & 30.0 & 26.0 & 37.6 & 34.8 \\
\hline Digitaria ciliaris & 2.9 & 4.6 & 10.3 & 8.51 & 15.7 & 6.3 & 8.4 & 6.9 & 15.7 & 11.1 & 4.9 & 6.8 \\
\hline Eleusine indica & 5.5 & 5.3 & 17.9 & 9.01 & 4.8 & 16.6 & 7.2 & 10.5 & 15.1 & 14.4 & 10.1 & 12.6 \\
\hline Eragrostis tenela & 5.7 & 6.4 & 4.4 & 5.49 & 6.8 & 7.0 & 4.2 & 5.8 & 3.3 & 4.3 & 4.4 & 3.4 \\
\hline Panicum distachyum & 0.0 & 0.0 & 2.3 & 1.21 & 0.0 & 2.8 & 3.0 & 3.6 & 0.0 & 3.8 & 1.4 & 11.1 \\
\hline Paspalum conjugatum & 0.0 & 0.0 & 0.0 & 0.00 & 0.0 & 0.0 & 0.0 & 1.5 & 0.0 & 0.0 & 0.0 & 0.0 \\
\hline \multicolumn{13}{|l|}{ Broadleaf } \\
\hline Aeschinomene americana & 0.0 & 1.4 & 0.0 & 0.98 & 0.0 & 0.0 & 0.0 & 0.0 & 0.0 & 0.0 & 1.3 & 1.8 \\
\hline Amaranthus spinosus & 3.5 & 1.9 & 1.5 & 3.94 & 9.2 & 4.3 & 8.8 & 2.2 & 7.3 & 3.6 & 1.5 & 3.9 \\
\hline Boerharavia erecta & 0.0 & 3.0 & 0.0 & 1.97 & 1.9 & 0.0 & 0.0 & 1.6 & 2.0 & 1.3 & 1.4 & 4.6 \\
\hline Cleome rutidosperma & 1.8 & 2.2 & 4.5 & 2.45 & 0.0 & 0.0 & 1.5 & 1.5 & 2.0 & 3.0 & 3.9 & 2.1 \\
\hline Croton hirtus & 0.0 & 3.7 & 0.0 & 0.98 & 0.0 & 2.0 & 1.5 & 1.7 & 0.0 & 1.3 & 0.0 & 0.0 \\
\hline Euphorbia heterophyla & 0.0 & 0.0 & 0.0 & 0.98 & 0.0 & 0.0 & 1.4 & 0.0 & 0.0 & 0.0 & 1.5 & 0.0 \\
\hline Euphorbia hirta & 1.2 & 1.7 & 0.0 & 0.00 & 0.0 & 0.0 & 0.0 & 0.0 & 0.0 & 2.5 & 1.3 & 0.0 \\
\hline Gynandropsis gynandra & 0.0 & 0.0 & 0.0 & 0.00 & 0.0 & 0.0 & 0.0 & 0.0 & 2.9 & 0.0 & 0.0 & 0.0 \\
\hline Hedyotis corymbosa & 4.7 & 0.0 & 3.2 & 3.47 & 1.9 & 1.4 & 0.0 & 1.7 & 1.9 & 3.1 & 1.3 & 0.0 \\
\hline Ipomoea triloba & 0.0 & 0.0 & 1.5 & 0.00 & 0.0 & 0.0 & 0.0 & 0.0 & 0.0 & 0.0 & 0.0 & 0.0 \\
\hline Lindernia ciliata & 6.4 & 1.4 & 1.5 & 2.68 & 0.0 & 0.0 & 3.2 & 0.0 & 0.0 & 3.1 & 3.3 & 0.0 \\
\hline Ocimum sanctum & 4.0 & 2.5 & 2.1 & 4.67 & 2.6 & 4.7 & 4.1 & 2.4 & 2.4 & 1.3 & 5.2 & 0.0 \\
\hline Philanthus niruri & 2.5 & 1.4 & 0.0 & 2.20 & 3.0 & 1.5 & 2.8 & 1.8 & 2.7 & 3.6 & 1.3 & 2.2 \\
\hline Physalis angulata & 1.3 & 0.0 & 2.0 & 1.48 & 0.0 & 0.0 & 1.7 & 0.0 & 0.0 & 0.0 & 3.1 & 0.0 \\
\hline Portulaca oleraceae & 0.0 & 0.0 & 0.0 & 0.00 & 0.0 & 0.0 & 0.0 & 0.0 & 0.0 & 0.0 & 0.0 & 0.0 \\
\hline Richardia scabra & 3.6 & 5.7 & 1.9 & 5.11 & 7.2 & 4.3 & 6.7 & 4.9 & 2.7 & 2.2 & 4.0 & 2.9 \\
\hline Synendrella nodiflora & 1.3 & 1.6 & 1.6 & 0.00 & 0.0 & 0.0 & 0.0 & 0.0 & 0.0 & 0.0 & 0.0 & 0.0 \\
\hline
\end{tabular}

Table 4. The effect of cultivars and nitrogen levels on weed nitrate reductase activity

\begin{tabular}{|c|c|c|c|c|}
\hline \multirow{2}{*}{ Cultivars } & \multicolumn{3}{|c|}{ Nitrogen Doses $\left(\mathrm{kg} \mathrm{N} \mathrm{ha}^{-1}\right)$} & \multirow{2}{*}{ Average } \\
\hline & 25 & 150 & 275 & \\
\hline Bisi 18 & $0.285 \mathrm{ab}$ & $0.111 \mathrm{c}$ & $0.075 \mathrm{c}$ & 0.157 \\
\hline NK33 & $0.225 \mathrm{~b}$ & $0.110 \mathrm{c}$ & $0.103 \mathrm{c}$ & 0.146 \\
\hline DK95 & $0.231 \mathrm{~b}$ & $0.129 \mathrm{c}$ & $0.063 \mathrm{c}$ & 0.141 \\
\hline Sukmaraga & $0.363 \mathrm{a}$ & $0.092 \mathrm{c}$ & $0.079 \mathrm{c}$ & 0.178 \\
\hline Average & 0.276 & 0.111 & 0.080 & $(+)$ \\
\hline
\end{tabular}

Note: Numbers in the same column followed by the same letter are not significantly different at the $5 \%$ level; $(+)$ : there is an interaction

Table 2 shows the increase of nitrogen dose could reduce the NRA in all cultivars. Sukmaraga with nitrogen dose of $25 \mathrm{~kg} \mathrm{~N}^{-1}$ had the highest nitrate reductase activity even though the value was not significantly different from that of Bisi 18, but significantly different from that of the other treatments. Between nitrogen doses of $150 \mathrm{~kg} \mathrm{~N}^{-1}$ and $275 \mathrm{~kg} \mathrm{~N} \mathrm{ha}^{-1}$, there was no difference in weed nitrate reductase activity of all cultivars. These show that in all cultivars, the application of the lowest dose of $25 \mathrm{~kg} \mathrm{~N} \mathrm{ha}^{-1}$ resulted in the highest NRA of the weeds.

Compared with NRA of corn plants of all cultivars, NRA of weeds was lower. NRA values in Bisi 18, NK 33, DK 95 and Sukmaraga cultivars were $0.335 \mu$ mol NO2-/ $g$ / hour, $0.237 \mu \mathrm{mol} \mathrm{NO} 2-/ \mathrm{g} /$ hour, $0.379 \mu \mathrm{mol} \mathrm{NO}{ }_{2}^{-} / \mathrm{g} /$ hour and $0.395 \mu \mathrm{mol} \mathrm{NO}{ }_{2}^{-} / \mathrm{g} /$ hour respectively. The application of $150 \mathrm{~kg} \mathrm{~N} \mathrm{ha}^{-1}$ and $275 \mathrm{~kg} \mathrm{~N}^{-1}$ resulted in lower value of weed NRA than that of the corn plants. Meanwhile, the nitrogen dose of $25 \mathrm{~kg} \mathrm{~N}^{-1}$ resulted in higher value of NRA of weed than that of corn plants.

\section{Leaf chlorophyll level}

Chlorophyll plays an important role in the process of photosynthesis. The results of the variance analysis showed there was no interaction between corn cultivars and various nitrogen doses on total amount of weed chlorophyll. The nitrogen dose had a significant effect on the total amount of weed chlorophyll, while the corn cultivars did not (Figure 2). 


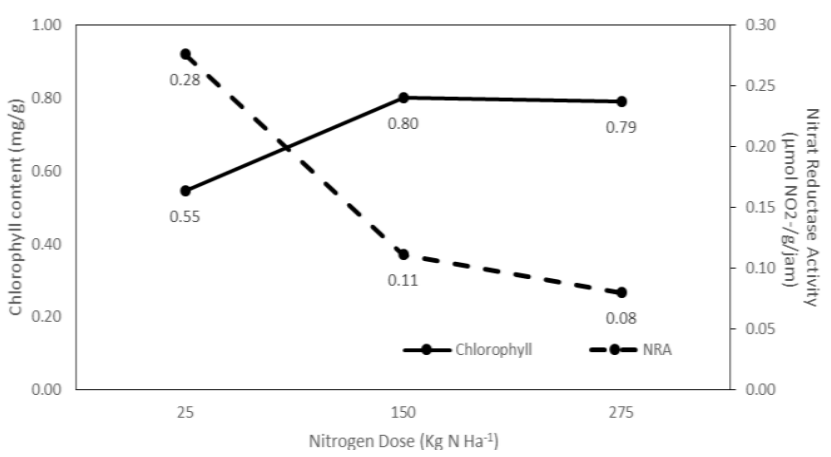

Figure 2. Weed nitrate reductase activity and total chlorophyll content on some nitrogen levels

Figure 2 shows that the application of $25 \mathrm{~kg} \mathrm{~N}^{-1}$ produced the lowest total chlorophyll in the weed leaves. The total chlorophyll content of weed leaves resulted from the application of $150 \mathrm{~kg} \mathrm{~N} \mathrm{ha}{ }^{-1}$ was not significantly different from that of $275 \mathrm{~kg} \mathrm{~N} \mathrm{ha}^{-1}$. This shows that to some extent the increased dose of nitrogen increases the level of total chlorophyll.

\section{Discussion}

The number of weed species that grew at corn plantation in 8 WAP decreased from that of 4 WAP. In 8 WAP the corn plants were taller, having more and wider leaves, so the ability of weed to survive decreased. In general, the weeds that survive were the types that can survive under lower sunlight intensity condition. In addition, the larger the cultivated plants' habitus, the more competitive they are, so only the weeds that have high competitiveness are able to survive.

Broadleaf weeds were the most widely growing weeds in 4 WAP and 8 WAP. This indicates that broadleaf weeds are the most persistent, as they generally have tap roots, so they are sturdier and dominating the corn plantation (Suryaningsih, Joni and Darmadi 2013). In 8 WAP, the generative phase of some corn cultivars was optimized which affected their ability in competing with weeds. Onarely et al. (2016) reported about Myristica fragrans Houtt plantation, showing that the number of weed species was different between immature stage (has not produced) and generating stage (has produced), i,e. 21 and 22 species respectively. Selaginella willdenowii Backer was the dominant weed species at the generating plant stage with SDR of $42.41 \%$ and at the immature plant stage with SDR of $34.38 \%$. This species is broadleaf.

Nitrogen is one of the elements which greatly affect plant growth. The nitrogen doses are given also affected the number of weed species that grew. Increasing nitrogen dose from $25 \mathrm{~kg} \mathrm{~N} \mathrm{ha}^{-1}$ to $150 \mathrm{~kg} \mathrm{~N} \mathrm{ha}^{-1}$ and $275 \mathrm{~kg} \mathrm{~N}^{-1}$ could reduce the number of weed species. Our data showed that the age of the plant also affected the diversity of weeds. The treatment combination of all corn cultivars with a dose of nitrogen $275 \mathrm{~kg} \mathrm{~N}^{-1}$ resulted in the smallest number of weed species, except by 33 NK. This shows that the application of $275 \mathrm{~kg} \mathrm{~N}^{-1}$ resulted in better plant growth than the other nitrogen doses so the weed growth was more suppressed and less able to survive. According to Cheimona et al. (2017), fertilization treatment has a significant effect on weed density and diversity.

Based on the data analysis, the nitrogen dose affected leaf area index and dry weight of weeds. According to Blackshaw et al. (2002), the response of each weed to nutrient application varies. Some species show a strong growth response to application of $\mathrm{N}$ or $\mathrm{P}$ while other species show strong responses to both nutrients. In some weeds, $\mathrm{P}$ application results in more dry weight than the $\mathrm{N}$ application.

At a nitrogen dose of $25 \mathrm{~kg} \mathrm{~N} \mathrm{ha}^{-1}$, leaf area index and dry weight of weeds were lower than at $150 \mathrm{~kg} \mathrm{~N} \mathrm{ha}^{-1}$ and $275 \mathrm{~kg} \mathrm{~N} \mathrm{ha}^{-1}$. At a dose of $25 \mathrm{~kg} \mathrm{~N} \mathrm{ha}^{-1}$, nitrogen availability was limited so there was competition between weeds and corn which affected the growth and leaf area of weeds: the weed leaves were narrower, so the leaf area index was lower. Conversely, at nitrogen doses of $150 \mathrm{~kg} \mathrm{~N}$ $\mathrm{ha}^{-1}$ and $275 \mathrm{~kg} \mathrm{~N} \mathrm{ha}^{-1}$ the nitrogen availability was higher, so competition was reduced: the leaves were wider and the weed leaf area index was greater. The low dose of nitrogen, about $25 \mathrm{~kg} \mathrm{~N} / \mathrm{ha}$ also influences the formation of the weed biomass. Nutrient deficiencies cause a slower rate of photosynthesis and, consequently, lower accumulation of biomass. Increasing doses of nitrogen to $150 \mathrm{~kg} \mathrm{~N} \mathrm{ha}^{-1}$ and $275 \mathrm{~kg} \mathrm{~N} \mathrm{ha}^{-1}$ increased the biomass because nitrogen need was sufficiently met. Nandan et al. (2018) reported that in paddy planted under aerobic condition the increase of $\mathrm{N}$ dose application also raised weed population and dry weight. In the second crop rotation, there was an increase in the species number and dry weight of weed by fertilizer application with lower dose than higher dose (Haliniarz et al. 2014).

The nitrate reductase enzyme plays an important role in nitrate metabolism. Increasing nitrogen dose from $25 \mathrm{~kg} \mathrm{~N}$ $\mathrm{ha}^{-1}$ to $150 \mathrm{~kg} \mathrm{~N} \mathrm{ha}^{-1}$ and $275 \mathrm{~kg} \mathrm{~N} \mathrm{ha}^{-1}$ caused a decrease of nitrate reductase activity. It caused weed and corn grew in same area, so the competition was high. The nitrate reductase activity in corns was higher than that in weeds. Latifa and Anggarwulan (2009) reported that the activity of nitrate reductase decreased with the addition of nitrogen fertilizer dose, then it increased at dose of fertilizer nitrogen $1.25 \mathrm{gm}^{-}$. The nitrogen dose also affects the leaf chlorophyll content. A dose of $25 \mathrm{~kg} \mathrm{~N} \mathrm{ha}^{-1}$ resulted in leaf total chlorophyll which was lower than that at the doses of $150 \mathrm{~kg} \mathrm{~N} \mathrm{ha}^{-1}$ and $275 \mathrm{~kg} \mathrm{~N} \mathrm{ha}^{-1}$. Higher nitrogen doses $\left(150 \mathrm{~kg} \mathrm{~N} \mathrm{ha}^{-1}\right.$ and $275 \mathrm{~kg} \mathrm{~N} \mathrm{ha}^{-1}$ ) could result in higher content of total chlorophyll. According to Ya-Wei (2018) chlorophyll is related to nitrogen. Stress of $\mathrm{N}$ low gives significant effect on chlorophyll content, photosynthesis and chlorophyll fluorescence. Nitrogen is one of the main components of the leaves chlorophyll which is about $60 \%$ and has functioned as enzymes and membrane proteins. The more chlorophyll content in the leaves the faster photosynthesis processes will run, producing more photosynthates (Sitompul, 1995).

In conclusion, broadleaf weeds were the most common weed found in the study site, but the most dominant weed was Dacytiloctenium aegyptium, which is a grass. There was no difference in nitrate reductase activity, total 
chlorophyll content, leaf area index and dry weight among cultivars. The nitrogen dose of $25 \mathrm{~kg} \mathrm{~N}^{-1}$ resulted in the lowest leaf area index and total chlorophyll content of the weed, but the highest nitrate reductase activity.

\section{REFERENCES}

Adigun JA, OS Daramola, OR Adeyemi, AO Ogungbesan, PM Olorunmaiye, OA Osipitan. 2018. J Exp Agric Intl 20 (2): 1-11, 2018.

Blackshaw RF, Brandt RN, Jansen HH. 2002. Weed dine out on nitrogen and phosphorus. Better Crops 86 (1): 20-22.

Cheimona N, CK Kontropoulou, A Papandreou, I Tabaxi, I Travlos, I Kakabouki, DJ Bilalis. 2017. Effect of N and P fertilization on weed flora of maize (Zea mays L.) crop. Bull UASVM Horticult 74 (1): 912.

Danususila H. 1989. Study of Nitrogen Effect from Artificial Fertilizers Against Nitrate Reductase Activity in the Garlic Leaves (Allium sativum L). [Thesis]. Universitas Gadjah Mada, Yogyakarta. [Indonesian]

Didon UME. 2002. Variation between barley cultivars in early response to weed competition. J Agron Crop Sci 188: 176-184.

Edesi L, Jarvan M, Adamson A, Lauringson E, Kuhtz J. 2012. Weed species diversity and community composition in conventional and organik farming: a five-year experiment. Žemdirbystė Agric 99 (4): 339-346.

Haden VR, Duxbury J M., DiTommaso A, Losey J E.. 2007. Weed community dynamics in the system of rice intensification (SRI) and the efficacy of mechanical cultivation and competitive rice cultivars for weed control in Indonesia. J Sustain Agric 30 (4): 5-26.

Haliniarz M, Gaweda D, Kwiatkowski C, Frant M, Boczula MR. 2014. Weed biodiversity in field pea under reduced tillage and different mineral fertilization conditions. Bulgarian J Agric Sci 20 (6): 13401348 .

Islam MS, Hasanuzzaman M, Rokonuzzaman M, Nahara K. 2009. Effect of split application of nitrogen fertilizer on morpho-physiological parameters of rice genotypes. International Journal of Plant Production (2009) 3 (1): 51-62

Kastanja AY. 2015. The type and dominance of weeds on sweet corn farm (a case study in Sub-district of Tobelo). Jurnal Agroforestri 10 (1): 66-72. [Indonesian]

Kolářová M, Tyšer L, Soukup J. 2015. Weed species diversity in The Czech Republic under different farming and site conditions. Acta Universitatis Agriculturae Et Silviculture Mendelianae Brunensis 63 (3): 741-749.
Latifa CI Anggarwulan E. 2009. The content of tissue nitrogen, nitrate reductase activity, and plants biomass of Xanthosoma sagittifolium on variations of shade and nitrogen fertilizers. Nusantara Biosci 1: 65-71.

Marsusi. 2012. Study of weed flora on community forest albizia plant environment in Boyolali. Ekosains 7 (1): -. [Indonesian]

Mashkova IV, Kruptonova TG, Kostryukova AM, Vlasov NE. 2018. Short Communication: Biodiversity of weeds in Ilmen State Reserve, Russia. Biodiversitas 19 (1): 106-111.

McNaughton, SJ, Wolf LL. 1990. General Ecology (Translation). Gadjah Mada University Press, Yogyakarta. [Indonesian]

Nandan N, Roy DK, Kumari P, Dharminder. 2018. Effect of weed management and nitrogen on weed dynamic and yield of rice under aerobic condition. Intl J Curr Microbiol App Sci 7 (4): 2738-2746.

Ndam LM, Enang JE, Mih AM, Egbe AE. 2014. Weed diversity in maize (Zea mays L.) fields in South Western Cameroon. Intl J Curr Microbiol App Sci 3 (11): 173-180.

Oksari AA. 2014. The analysis of weed vegetation in maize and its relation to the control of weeds in Lambung Bukit, Padang, West Sumatra. Jurnal Sains Natural Universitas Nusa Bangsa 4 (2): 135142. [Indonesian]

Onarely A, Riry J, Wattimena AY. 2016. The study on weed community in Mirystica fragrans Houtt area on immature stadium plants and produce plants in Rutong village Subdistrict of Leitimur Selatan Ambon. J. Budidaya Pertanian 12 (2): 80-88. [Indonesian]

Pachta EKR, Rule DM, Dille JA. 2013. Corn and palmer amaranth (Amaranthus palmeri) interactions with nitrogen in dryland and irrigated environments. Weed Sci 61: 249-258.

Rao VS. 2000. Principles of Weed Science. Science Publishers, USA.

Salehian H, Eshaghi O. 2012. Growth analysis some weed species. Intl J Agric Crop Sci 4 (11): 730-734.

Sitompul SM, Guritno B. 1995. Plant Growth Analysis. Gadjah Mada University Press, Yogyakarta. [Indonesian]

Sunaryo, Girmansyah D. 2018. Identification of plants invasive species in Tanjung Puting National Park, Central Kalimantan. Pros Sem Nas Masy Biodiv Indon 1 (5): 1034-1039. [Indonesian]

Suryaningsih, Joni M, Darmadi AAK. 2013. Inventarisasi gulma pada tanaman jagung (Zea mays L.) di lahan sawah Kelurahan Padang Galak, Denpasar Timur, Kodya Denpasar, Provinsi Bali. Jurnal Simbiosis 1 (1) : 1-8. [Indonesian]

Tohari. 2017. Limiting of Plant Growth. In: Tohari (eds). The Basic Aspect of Sustainability Agronomy. Gadjah Mada University Press, Yogyakarta. [Indonesian]

Wu YW, Li Q, Jin R, Chen W, Liu XL, Kong FL, Ke YP, Shi HC, Yuan JC. 2018. Effect of low-nitrogen stress on photosynthesis and chlorophyll fluorescence characteristics of maize cultivars with different low nitrogen tolerances. J Integrat Agric. DOI: DOI: 10.1016/S2095-3119(18)62030-1 